\title{
Religion, Children and Employment: The Baby Loup Case
}

\section{Abstract:}

The aim of this article is to offer a systematic analysis of the French Cour de cassation's plenary Chamber final decision on the Baby Loup case in which it was held that a private nursery had lawfully required one employee to remove her jilhab at work, in accordance with the general religious neutrality requirements contained in the nursery's policy. The article examines the decision in light of ECtHR and French domestic legal requirements. First, I argue that laïcité -rightly- held to be irrelevant still unduly taints the reasoning. As a result, proportionality and anti-discrimination provisions are not properly applied. Secondly, I compare and contrast the decision to recent ECtHR cases, notably to Eweida and Others $v$ UK. I argue that a Baby Loup-type restriction does not meet ECHR standards. Besides, the margin of appreciation, recently used by the ECtHR to save the French ban on the full-covering of the face in the $S A S$ case, is unlikely, as will be demonstrated, to come into play in a Baby Loup context.

\section{INTRODUCTION}

On 25 June 2014, the French Cour de cassation in its plenary Chamber decision ruled that a private nursery known as Baby Loup had lawfully required one employee to remove her non-face covering Islamic jilhab at work, ${ }^{1}$ in accordance with the general religious neutrality requirements contained in the nursery's policy. ${ }^{2}$ The decision, which put an end ${ }^{3}$ to six years of litigation, follows four prior decisions on the case. The first two decisions ruled in favour of the nursery: both the employment tribunal ${ }^{4}$ and the Court of appeal of Versailles ${ }^{5}$

\footnotetext{
${ }^{1}$ The employee wished to wear a jilbab, that is a long coat garment covering the whole body and the hair but leaving the face visible. Leaving the face visible, the jilhab would not fall under the French 2010 Law (Loi no 2010-1192, JO 12 October 2010, 18344) which was passed to prohibit full-face-covering garments in all public spaces, including the workplace if it is open to the general public. ${ }^{2}$ Cass Ass Plén 25 June 2014, (2014) Rec D 1386.

3 The issue could however be raised again before the European Court of Human Rights. See reporting the employee's intention to challenge the Plenary Cour de cassation decision in Strasbourg, http://www.huffingtonpost.fr/2014/06/25/cedh-vincent-lambert-affaire-baby-louppresentation-institution-europenne_n_5526082.html [accessed 27 March 2015].

${ }^{4}$ Conseil des Prud'hommes Mantes-la-Jolie 13 December 2010, (2011) Rec D 85 and (2012) Rec D 904, Comments by J Porta.

${ }^{5}$ CA Versailles 27 October 2011, (2012) Revue de Jurisprudence Sociale 106.
} 
had - for different reasons $-{ }^{6}$ upheld the employee's dismissal. However, following a referral ${ }^{7}$ to the Cour de cassation, the outcome temporarily shifted in favour of the employee. In 2013, the Social Chamber of the Cour de cassation held that general religious neutrality duties could not be imposed by a private employer. ${ }^{8}$ Notwithstanding the absence of a system of precedent in French procedural law, ${ }^{9}$ the 2013 Cour de cassation decision should have sealed the debate. Albeit not legally binding, Cour de cassation decisions are usually followed by lower courts. ${ }^{10}$ Unexpectedly in this case, the Court of appeal of Paris,${ }^{11}$ to which the case was remanded, did not however apply the 2013 ruling. The 2013 Social Chamber of the Cour de cassation had held that general religious neutrality requirements could not be imposed throughout the nursery. The 2013 decision thus emphasized the strong divide that exists in France between private agents, who are entitled to the protection provided under the French Employment Code and public agents who, as representative of the State, are bound by special duties. ${ }^{12}$ The absence of religious symbols in France is regarded as an emblem of a state philosophy—-to be reflected in key national institutions and respected by public agents. ${ }^{13}$ The separation between state and religion, as construed under the French conception of laïcité, thus imposes a duty of restraint on public agents. ${ }^{14}$ However, as the Cour de cassation held in its 2013 decision, such reasoning cannot be extended into the private sphere to restrict individual freedoms enjoyed by private employees. A private employer could not therefore, according to the 2013 Cour de cassation decision, avail himself of the requirements of laïcité in order to circumvent the protection against discrimination in the workplace. Swapping legal basis and relying on provisions not discussed before the Cour de cassation in 2013, the Court of appeal of Paris held that, on the facts, the restrictions on the employee's rights were justified by the laïc ethos which the nursery was allegedly promoting. ${ }^{15}$ Following an inevitable further referral, the Cour de cassation in plenary

\footnotetext{
${ }^{6}$ According to the employment tribunal, the nursery's activities could be characterized as a public service hence triggering the application of laïcité and general religious neutrality requirements. In contrast, for the Court of appeal of Versailles, religious neutrality requirements were mandated by the nursery's mission: offering care to young children.

${ }^{7}$ The term 'referral' is used rather than 'appeal' because Court of appeal decisions in France can only be challenged on points of law. The functions of the Cour de cassation are primarily to review the legal basis of decisions reached by the Court of appeal, rather than to act as a third level of appeal on the merits. For an explanation in English of the French court system, see J Bell, S Boyron, and S Whittaker, Principles of French Law (OUP $2^{\text {nd }}$ ed 2008), chapter 2. Adde, J-L Aubert, 'La Distinction du fait et du droit dans le pouvoir en cassation en matière civile' (2004) Rec D 2239.

${ }^{8}$ Soc 19 March 2013, (2013) Rec D 962; Opinion B Aldigé at 956; Comments J Mouly at 963 and J Porta at 1026.

${ }^{9}$ See by contrast, reaffirming the importance of the adherence to the doctrine of precedent in English Law, Supreme Court 3 November 2010 Pinnock v Manchester City Council [2010] UKSC 45.

${ }^{10} \mathrm{P}$ Deumier, 'La Doctrine de la Cour de cassation : opinion ou précédent ?, observations sous Cass Com 8 novembre 2005 , Bull IV n 219, 235 et Cass Soc 13 septembre 2005, Bull V n 253, 222', (2006) 1 RTC 73.

${ }^{11}$ CA Paris 27 November 2013, (2014) Rec D 65, Comments by J Mouly.

${ }^{12}$ See for further comments and analysis on the divide between private and public agents, infra section B.

${ }^{13}$ Myriam Hunter-Henin, 'Why the French Don't Like the Burqa: Laïcité, National Identity and Religious Freedom' (2012) 61 ICLQ 1, 9.

${ }^{14}$ See CE avis 3 May 2000 Mlle Marteaux, (2011) RFDA 141, Conclusions R Schwartz.

${ }^{15}$ The Court of appeal of Paris put laïcité back into the equation on the basis of article 4(2) of the Council Directive 2000/78/EC of 27 November 2000 which allows churches, religious associations or communities as well as philosophical and non-confessional organizations to promote a special ethos. Staff employed by these institutions may legitimately be expected to show a certain degree of allegiance to the ethos promoted by the employer's institution even at some cost to their individual freedom to manifest differing beliefs. See Official Journal
} 
Chamber ${ }^{16}$ reached a final decision in 2014. According to the 2014 decision, the Court of appeal of Paris had erred in its choice of legal basis but had nevertheless reached the correct outcome. Laïcité, confirmed the plenary Chamber, was not applicable. However, it added, a general ban could still meet legal proportionality and anti-discrimination requirements. Following the Court of appeal of Paris' findings, the Cour de cassation then went on to rule that in a small nursery where all members of staff came into contact with children, concerns for children's freedom of conscience could warrant a general obligation of religious neutrality. Moreover, the Court did not think it necessary to examine whether the restriction amounted to discrimination on the ground of religion presumably because, adopting the Procureur général's non legally binding opinion, ${ }^{17}$ the employee concerned was still free to hold her Muslim beliefs. The Court of appeal of Paris' conclusion that the dismissal had been fair and justified was consequently upheld.

The case is interesting in many respects: it illustrates the legal complexities underlying religious claims in employment contexts and the intertwining of various layers of norms that are potentially applicable. ${ }^{18}$ Freedom of religion in the workplace may be covered by Council Directive 2000/78/EC of 27 November 2000 (thereafter the Directive) establishing a general framework for equal treatment in employment and occupation. ${ }^{19}$ It will also fall under the ambit of article 9 of the European Convention on Human Rights (thereafter ECHR) which guarantees everyone the right to hold and to manifest religious beliefs. Both provisions are directly applicable before French national Courts. The former was entrenched into the French Employment Code, under article L 1321-3, by the French law of 27 May $2008^{20}$ and has thus become part of French domestic law. The latter is routinely raised by French litigants against French Acts of Parliament. On the basis of article 55 of the French Constitution whereby regularly ratified international Treaties are directly applicable ${ }^{21}$ French Courts regularly review the compatibility of French legislative provisions with ECHR requirements and set aside any provision deemed to be conflicting. ${ }^{22}$ Besides French courts interpret French domestic law in a sense that is

L 303, 02/12/2000 P. 0016, available at http://eur-lex.europa.eu/legalcontent/EN/TXT/?uri=CELEX:32000L0078 accessed 2 October 2014 accessed 2 October 2014.

${ }^{16}$ In such rare instances of two consecutive deferrals to the Cour de cassation in the same case on the same grounds, the second deferral is necessarily examined in plenary chamber. The decision of the plenary chamber is then final and binding on lower courts. See $\mathrm{J}$ Boré and $\mathrm{L}$ Boré, La Cassation en matière civile (Dalloz 2003).

${ }^{17} \mathrm{http} / / /$ www.courdecassation.fr/IMG/Avis_PG_pleniere_140625ano.pdf accessed 25 March 2015.

${ }^{18}$ See T Lock, 'An Additional Protective Layer: The Case of Religious Discrimination in the United Kingdom and Germany' (2013) 38(5) ELRev 655.

${ }^{19}$.Supra (n 15)

${ }^{20}$ Loi n 2008-496 of 27 May 2008 portant diverses dispositions d'adaptation au droit communautaire dans le domaine de la lutte contre les discriminations (Act Implementing EU Law Anti-Discrimination provisions), available at http://www.legifrance.gouv.fr/affichTexte.do?cidTexte=JORFTEXT000018877783 accessed 24 September 2014.

${ }^{21}$ According to article 55 of the French Constitution, direct effect of international treaties is subject to a condition of reciprocity. But this condition does not apply to treaty on human rights. See F Sudre, 'La Dimension internationale et européenne des libertés et droits fondamentaux', in R Cabrillac, M-A Frison-Roche \& T Revet, Libertés et droits fondamentaux, (Dalloz 18th ed 2012 ), 35.

${ }^{22}$ Such review has been carried out by French private law courts since the important decision of Cass Civ 24 May 1975 Jacques Vabre, (1975) Rec D 496, Conclusions Touffait. The Jacques Vabre case deals with a provision of the EC Rome Treaty but its reasoning can be (and was indeed) extended to the European Convention of Human Rights. Similar review has been carried out by French administrative law courts since the decision of the French Conseil d'Etat of 20 October 1989, (1989) Rec Lebon 108243. 
compatible with ECHR requirements. ${ }^{23}$ Yet, as will be shown below, neither anti-discrimination or religious freedom requirements were properly applied or correctly construed by the French Cour de cassation in its final 2014 Baby Loup decision. As well as sitting at the crossroads of several legal regimes (anti-discrimination and human rights protection frameworks) and of several legal orders (EU, Council of Europe and national orders), religious claims in employment contexts are often emblematic of constitutional values which touch on the specificities of national Church/State arrangements and legal traditions. Through the concept of margin of appreciation granted to Member States by the $\mathrm{ECtHR}^{24}$ or the respect for national identities, under article 4(2) of the Treaty of the European Union, ${ }^{25}$ both the ECtHR and the Court of Justice of the European Union (thereafter CJEU) will usually shy away from encroaching onto deeply felt constitutional values. However, as will be demonstrated below, no such core values are at stake in Baby Loup.

The aim of this article is to offer a systematic analysis of the Baby Loup decision in light of ECHR and of French domestic legal requirements. First, I will carry out an internal critique of the decision. It is submitted that the Baby Loup 2014 decision places an undue burden on religious (and especially female Muslim) employees working in the childcare sector in France. Secondly, I will examine the Baby Loup decision in light of ECtHR case-law. It will be argued that a Baby Loup-type restriction would not meet ECHR standards. ${ }^{26}$

\section{AN INTERNAL CRITIQUE}

The Baby Loup 2014 decision superficially seems to follow orthodox French legal reasoning: the Cour de cassation resists the temptation to inflate laïcité beyond its usual remit and confirms instead the applicability of French employment law provisions. However, on a closer look, laïcité, despite having been formally set aside, still taints the Cour de cassation's reasoning. As a consequence, proportionality and anti-discrimination protections are summarily dealt with and religious neutrality firmly guaranteed. It is submitted that the restriction imposed by the nursery's policy should on the contrary have been held to amount to a disproportionate and discriminatory restriction on individual religious freedom. The reason for the Cour de

\footnotetext{
${ }^{23}$ English Courts are expected to do likewise under section 3 of the Human Rights Act (thereafter HRA) whereby, '1) So far as it is possible to do so, primary legislation and subordinate legislation must be read and given effect in a way which is compatible with the Convention rights'. Moreover, under section 6 HRA, Courts, as public authorities must not act in a way which is incompatible with a Convention right. However contrary to French courts, English Courts have not been persuaded by their status under section 6 HRA to absorb Strasbourg principles directly into private law. See J Wright, 'A damp squib? The impact of section 6 HRA on the common law: horizontal effect and beyond' (2014) PL 289.

${ }^{24}$ For an illustration, see See ECHR 18 March 2011 Lautsi v Italy (App no 30814/06), 68.

${ }^{25}$ See A Von Bogdandy and S Schill, 'Overcoming Absolute Primacy: Respect for National Identity under the Lisbon Treaty' (2011) 48 CMLRev 1417.

${ }^{26}$ For reflections on the case in light of EU requirements, see Myriam Hunter-Henin, 'Living Together in an Age of Religious Diversity: Lessons from Baby Loup and SAS' (2015) OJLR 1, 11-13, 18.
} 
cassation holding otherwise lies in the unconvincing abstract assumptions underlying its reasoning. The Cour de cassation relies on the assumption that the wearing of ostentatious religious symbols by nursery assistants is necessarily harmful to the young children attending the nursery. A concrete evidence-based assessment of the facts would have led to a more rigorous and fairer treatment of the case.

\section{$\underline{\text { A Disproportionate and Discriminatory Restriction }}$}

According to the Cour de cassation's final 2014 decision on Baby Loup, the case fell under private employment law. It thus rejected the views of the employment tribunal, which had brought the case under the public law remit by characterizing the nursery's mission as one of public service, and of the Court of appeal of Paris, which had sought to justify general religious neutrality duties by referring to the laïc ethos which the nursery was allegedly promoting. The Cour de cassation held in 2014 that the case was irrefutably a purely private law case. As such private law employment provisions applied and in particular articles L1121-1 and L1321-3 of the French Employment Code. According to the former, any restrictions onto individual freedom in the workplace must be justified in light of the employee's task and be proportionate to the aim pursued. Moreover, according to the latter article L1321-3, incorporated by the French law of 27 May $2008,{ }^{27}$ in pursuance of the Directive, ${ }^{28}$ restrictions of a discriminatory nature must be justified by an essential requirement and be proportionate to the goal sought. The issue was therefore whether the contested provision contained in the nursery's policy complied with those articles. The policy stated that 'rights to freedom of conscience and freedom of religion recognized to staff members could not be invoked to undermine the principles of laïcité and neutrality which applied across all of the nursery's activities both within the nursery's premises and outside, on visits organised for the children'.

The two Cour de cassation decisions -the Social Chamber decision of $2013^{29}$ and the plenary Chamber decision of $2014{ }^{30}$ differ radically in their assessment of the proportionality of the restriction. For the Social Chamber, a general requirement of neutrality is not proportionate because of its wide ambit -all staff, without any distinction, are affected by the prohibition which moreover applies across all of the nursery's activities and in all of the nursery's premises. Furthermore, because this requirement is more likely to affect Muslim women, it constitutes an indirect discrimination. This, I contend, was the correct analysis and logical conclusion to reach. ${ }^{31}$ The Cour de cassation in 2014 however thought otherwise: the restriction, despite its wide scope within

\footnotetext{
${ }^{27}$ Supra, (n 20).

${ }^{28}$ Supra (n 15).

${ }^{29}$ Supra (n 8).

${ }^{30}$ Supra (n 2).

${ }^{31}$ See also, F Laronze, 'Affaire Baby-Loup: l'épuisement du droit dans sa recherche d'une vision apolitisée de la religion' (2014) Droit social 100; M Peyronnet, 'Baby-Loup: passage en force des juges d'appel', (2013) Rec D Actualités.
} 
the company, was proportionate. This conclusion relies on the particular constraints weighing upon the nursery, notably its small size which mandated that all members of staff come into contact with the children in its care and its location in a multi-confessional socially deprived area where the risk of religious tensions was thought to be particularly harmful. Assuming for now that the exposure to religious symbols may indeed inherently jeopardize the social harmony of the locality and put children's freedom of conscience at risk, it remains difficult to understand why intermittent contact with children should justify permanent full-time restrictions on religious manifestation in the workplace. The plenary Chamber of the Cour de cassation claims to have carried out a concrete assessment of proportionality requirements: looking beyond the wording of the contested clause, it considered the surrounding context and took into account the particular structure and specific goals of the Baby Loup nursery. It is submitted that this so-called contextual approach is in reality abstract in nature. The scope of the restrictions indeed relates to the special character attributed to the institution but it ignores how they might be connected (or not) to the specific tasks assigned to the employee concerned. ${ }^{32}$

The loose and abstract assessment of proportionality requirements in this case contrasts with the detailed scrutiny manifested in previous French case-law. For example, in previous French administrative caselaw relating to bans imposed on alcohol consumption in the workplace, ${ }^{33}$ French courts have subjected company policies to a minute scrutiny. According to French national regulations, no alcoholic beverage is authorized in work cafeterias except for wine, beer, cider and perry. ${ }^{34}$ The employer may decide to introduce further restrictions but only if they pursue a legitimate aim and are proportionate. In 2012, the French Conseil d'Etat therefore struck down the outright ban on alcohol consumption implemented by the Company Caterpillar on one of its French sites.$^{35}$ However legitimate the aim pursued was, namely the protection of health and safety at work, the restrictions failed to be specifically justified and proportionate to the tasks performed by the employees concerned. Caterpillar had imposed a general ban which applied to all members of staff without any distinction and throughout the day, including at meal times. The insistence of the Conseil d'Etat on specific justifications thus radically contrasts with the summary approval by the Cour de cassation of the general religious neutrality

\footnotetext{
${ }^{32}$ For a plea in favour of a more robust use of proportionality requirements in law and religion cases, see $M$ Hunter-Henin, 'Believing in Negotiation: Reflection in Law's regulation of Religious Symbols in State Schools' in F Guesnet and al, Negotiating with Religion (Ashgate forthcoming). More generally, see the debate in the International Journal of Constitutional Law, S Tsakyrakis, 'Proportionality: An Assault on Human Rights?' (2009) 7 Int'1 J Const L 468 and (2010) 8 Int'1 J Const L 709; M Klatt and M Meister, 'Proportionality - A Benefit to Human Rights? Remarks on the I CON Controversy' (2012) 10 Int'1 J Const L 687. Adde, J Rivers, 'The Presumption of Proportionality' (2014) 77(3) MLR 409.

${ }^{33}$ Private company policies are subject to inspections by work inspectors (inspecteurs du travail) who are civil servants. But the policy remains a private law regulation (see Cass Soc 16 December 1992, Bull Civ V n 602). As such challenges to the policies of private companies will normally fall under the jurisdiction of private law courts. However in the Caterpillar case, the challenge to the company's policy was raised by the work inspector and consequently fell under the jurisdiction of administrative law courts.

${ }^{34}$ Art R 4228-20 of the French Employment Code.

${ }^{35}$ CE 12 November 2012, JCP E 2012 Act 745, D Corrighan-Coursin.
} 
requirements in Baby Loup. There is no reason why the freedom to manifest religious beliefs should be treated differently to any other fundamental freedom. On the contrary the ECtHR has underlined the importance that Member States need to attach to religious freedom claims in an employment setting. ${ }^{36}$ If there is to be an implicit hierarchy, one might expect that the freedom to manifest religious beliefs would be higher up than the liberty to have wine at meal times. To justify this unduly low status conferred to employees' religious freedom rights, the plenary Chamber of the Cour de cassation refers to the specificities of the child care sector. However, as will be shown below, no evidence supports this suggestion that child care sector employees should automatically enjoy a lesser degree of religious freedom than other rivate law employees.

\section{$\underline{B \text { Specific Rules for Child Care Sector Employees }}$}

Following constant French administrative case-law, ${ }^{37}$ the plenary Chamber of the Cour de cassation held that the principle of lä̈cité was not applicable to nursery staff. Yet, surprisingly, the religious neutrality duties associated with the principle of laïcité could nevertheless, according to the plenary Chamber of the Cour de cassation, be imposed on all nursery employees. The Cour de cassation in plenary Chamber first confirmed that laïcité was not relevant to the case. Under French Law, laïcité (and the religious neutrality duties it carries for employees) may extend at times to private companies but only if these companies are entrusted with a mission of public service. ${ }^{38}$ The general public interest pursued by the nursery and the substantial public funding it received did not suffice to characterize its activity as a mission of public service. According to French administrative case-law, activities will only be classified under the public banner if they are carried out under the control of public authorities. Those subtle divisions may be criticized. Some have argued that all missions of general interest should amount to public service missions ${ }^{39}$ whilst others -like the author- ${ }^{40}$ have queried the legitimacy of imposing religious neutrality duties upon private law employees. But whatever the position, it was not for the Cour de cassation in Baby Loup to question the established case-law on the confines of laïcité. The plenary Chamber is therefore to be praised for its restraint. ${ }^{41}$ However, having set lä̈cité aside, the Cour de cassation should have done the same in my view with religious neutrality requirements. The Court of appeal of

\footnotetext{
${ }^{36}$ ECHR 15 January 2013 Eweida and Others v. UK (App nos 48420/10; 59842/10; 51671/10 and 36516/10).

${ }^{37}$ CE 28 June 1963 Narcy, Grands arrêts de la jurisprudence administrative 293 and CE 22 February 2007 APREI (association du personnel relevant des établissements pour inadaptés), Grands arrêts de la jurisprudence administrative 294.

${ }^{38}$ For an overview of the debates surrounding the definition of 'public authorities' and 'hybrid public authorities' in English Law, see D. Oliver, 'The frontiers of the State: public authorities and public functions under the Human Rights Act' (2000) PL 476.

${ }^{39}$ F Rome, 'Baby Loup dans la bergerie', (2013) Rec D 761; M Peyronnet, 'Laïcité et illicéité du règlement intérieur d'une entreprise ne gérant pas un service public’ (2013) Rec D Actualités. 40

${ }^{41}$ Contra, F Champeaux, Comments (2014) Semaine Sociale Lamy, 1367; S Mouton and T Lamarche, 'Affaire Baby Loup: suite et fin? Une décision en demi-teinte qui ne protège pas la neutralité nécessaire aux missions d'intérêt général' (2014) AJDA 1842.
} 
Paris had held that a laïc ethos could be inferred from the nursery's goals. Whilst the Cour de cassation in plenary Chamber refutes the idea that laïcité could be relegated to a mere belief or ethos, ${ }^{42}$ it follows in effect the reasoning of the Court of appeal of Paris. Despite the more rigorous use of terminology, the plenary Chamber of the Cour de cassation, like the Court of appeal of Paris, assumes that a policy of social cohesion and protection of children presupposes the concealment of religious signs. Such reasoning -which does not rely on any concrete evidence that the children were in any way troubled by the sight of non-face covering Islamic dress- does not promote children's emerging freedom of conscience but only the secularization of French society. It is submitted that such endeavours do not rely on any other rationale but the widely-held suspicions in France towards religion and in particular towards Islam. ${ }^{43}$ As such, and despite the recent acknowledgment of similar suspicions in the $S A S$ case, ${ }^{44}$ it is submitted that a Baby Loup-type restriction contravenes ECHR requirements.

\section{A EUROPEAN CRITIQUE}

As shown above, the 2014 Cour de cassation Baby Loup decision dismissed arguments based on reasoning from anti-discrimination and human rights protection summarily. One explanation for this treatment is the reliance placed on the ECtHR's decision of Dahlab $v$ Switzerland, ${ }^{45}$ in which the Islamic scarf is portrayed as a powerful religious symbol susceptible to exercise an (undue) influence on young children. It is submitted however that Dahlab does not offer irrefutable support for the Cour de cassation's final decision in Baby Loup. First, recent ECtHR cases suggest that religious freedom claims can no longer be summarily dismissed. Secondly, the assumption that non-face covering Islamic dress will necessarily conflict with children's freedom of conscience an no longer be entertained.

\section{$\underline{\text { A. Outdated Filters }}$}

Statements in the recent SAS decision have revealed that the ECtHR will now be more attentive to the dilemmas faced by individuals in such situations. In $S A S$, the ECtHR was sensitive to the impossible choice faced by the claimant: either to give up fully covering up her body and face, contrary to what she felt her religious beliefs

\footnotetext{
${ }^{42}$ According to Frédéric Dieu, the Cour de cassation thus avoids splitting lä̈cité into two notions: one portraying lä̈cité as an overarching constitutional principle and another depicting laïcité as an ethos: 'L'affaire Baby Loup: quelles conséquences sur le principe de laïcité et l'obligation de neutralité religieuse?' (2014) JCP A 2114.

${ }^{43}$ On the difficult reconciliation of Islam and French secularism, see JR Bowen, Can Islam Be French? Pluralism and Pragmatism in a Secularist State (Princeton University Press 2011).

${ }^{44}$ ECHR 1 July 2014 SAS v France (App no 43835/112014)

${ }^{45}$ ECHR 15 February 2001 Dahlab v Switzerland (App no 42393/98).
} 
demanded or to face criminal sanctions. There is no doubt that the ECtHR would show particular concerns for the sacrifice that the Baby Loup nursery employee was forced to make: giving up wearing the jilbab at work, contrary to her religious beliefs or giving up her job altogether.

\section{The outdated specific situation rule}

The specific situation rule, also known as the contracting-out approach, whereby employees are deemed to have willingly agreed to religious restrictions under the terms and conditions of their employment contract, has now been explicitly abandoned by the ECtHR in Eweida and Others. ${ }^{46}$ This approach, also favoured by English courts, ${ }^{47}$ is nevertheless still implicit in the 2014 Cour de cassation's reasoning. The fact that the Baby Loup nursery's policy already contained a religious neutrality clause (albeit a weaker version) when the employee joined the nursery is (wrongly) held against her. The reasoning adopted by the 2014 Cour de cassation decision is therefore problematic from a ECHR perspective.

\section{An outdated appraisal of children's fundamental rights}

The substantive rationale put forward by the Cour de cassation -respect for children's freedom of conscience- is even more contentious. The ECtHR has in the past appeared to share some of the Cour de cassation's concerns towards the wearing of the Islamic dress in presence of children. In Dahlab v Switzerland, ${ }^{48}$ a primary school teacher teaching in a state school in Geneva was dismissed for having refused to remove her Islamic scarf. The Swiss Courts upheld the dismissal on the basis of the principle of laïcité which applied in the Geneva Swiss Canton. ${ }^{49}$ The ECtHR approved the position of the Swiss authorities. Many of the Court's statements in Dahlab seem to be relevant to Baby Loup:

The Court accepts that it is very difficult to assess the impact that a powerful external symbol such as the wearing of a headscarf may have on the freedom of conscience and religion of very young children. The applicant's pupils were aged between four and eight, an age at which children wonder about many things and are also more easily influenced than older pupils.

It is not absolutely certain that these factors would apply mutatis mutandis to nursery French children who are under 3 years of age. At such a young age, children might not have reached the questioning phase referred to in Dahlab and their encounters with their nursery carer might be less frequent than the daily contacts between

\footnotetext{
${ }^{46}$ Supra (n 36), para 83.

${ }^{47}$ See M Hill, R Sandberg and N Doe, Religion and Law in the United Kingdom (Wolters-Kluwer 2011), 53.

${ }^{48}$ Supra (n 45).

${ }^{49}$ Art 164 et seq of the Cantonal Constitution.
} 
school children and their teacher. But more importantly a private nursery employee cannot equate to a state school teacher teaching in a laïc country. The applicant in Dahlab was acting as a representative of the State. This special status allowed a greater deference for the respondent State. No such representative status on the other hand could be associated with the functions of the Baby Loup private nursery employee. It is true that in more recent cases, the ECtHR has also, more controversially, been willing to grant a wide discretion to national authorities where the infringed individual rights allegedly clashed with common national values. As will be shown below however, the common values appealed to in Baby Loup are unlikely to be granted such prevailing force.

\section{B. Common Values}

The Cour de cassation approved the general restriction imposed in Baby Loup in the name of children's fundamental rights. As will be demonstrated below, this justification in fact hides a more general political goal of secularizing French society as well as considerations for parental preferences. In this section I will argue, relying on the most recent ECtHR case-law, that neither of these hidden agenda should prevail over the employee's religious freedom rights.

\section{Religious neutrality and social integration: comparison with the $S A S$ case $e^{50}$}

The aim of the paragraph is to prove that the social considerations which proved decisive in the $S A S$ case cannot be transferred to a Baby-Loup type scenario. Many of the Court's statements in Baby Loup refer to the need to protect social harmony. According to the nursery's statutes, the aim pursued by the Baby Loup nursery was to promote the integration of women living in socially deprived areas and offer childcare to babies and toddlers. The Court of appeal of Paris ${ }^{51}$ and the plenary Chamber of the Cour de cassation ${ }^{52}$ both infer from these goals a duty of religious neutrality. However, whether separately or jointly, it is not shown why the aims of preserving social cohesion and children's rights should warrant strict religious neutrality. Despite a similar lack of evidence, the ECtHR, in SAS v France, was content to uphold a general ban on fully-face covering clothing for the sake of protecting the minimum requirements of living together. ${ }^{53}$ Given the importance of the face in our contemporary societies, the ECtHR accepted that wearing the burqa could be perceived as putting social harmony into

\footnotetext{
${ }^{50}$ Supra (n 44).

${ }^{51}$ Supra (n 11).

${ }^{52}$ Supra (n 2).

${ }^{53}$ Supra (n 44).
} 
jeopardy.$^{54}$ The suggestion that social harmony necessarily entails a duty of social interaction at all times is highly questionable. It is beyond the scope of this article to analyze the reasoning of the ECtHR in $S A S .^{55}$ Suffice it to say here that the rationale put forward to uphold the French ban on the burqa cannot be transferred to uphold a Baby Loup-type restriction. Neither of the two factors emphasized to justify the outcome in SAS are present in Baby Loup. The restriction no longer applies to face-covering garments only but to all forms of religious manifestations. The restriction no longer expresses a national choice of society but a company policy. The restriction is thus no longer mandated by public policy but left to the discretion of each particular employer. The ECtHR in SAS was sensitive to the strong political support gathered behind the French law on the burqa ${ }^{56}$ Moreover the deeply-felt national Republican values which had permeated the debates preceding the French Law undoubtedly encouraged the ECtHR to show some restraint, lest it might be accused of impinging on constitutional arrangements. ${ }^{57}$ A decision of violation in a Baby Loup context would not have the same political resonance. The restriction was not the result of intense impassionate national debates about the core of French Republicanism nor was it passed by a strong majority in Parliament. The prohibition imposed in Baby Loup was decided by an individual employer and upheld by the plenary Chamber of the Cour de cassation against the conclusion of the specialised Social Chamber. Whether in SAS or Baby Loup, the common values called upon to justify the interference with religious freedoms offer but a thin legal basis. However in SAS the importance of these common values for French society had been solemnly emphasized both by the French Parliament ${ }^{58}$ and the French Constitutional Council. ${ }^{59}$ By contrast, the role assigned to common values is far less prominent in Baby Loup. If social cohesion and children's rights were really at stake in Baby Loup, their protection should not be optional and depend on whether the employer concerned had inserted a clause to that effect in the nursery policy. As it stands, the Baby Loup case displays a curious entanglement of corporate and general interests: company policies are not usually assigned public policy missions such as solving social problems of integration or protecting children's fundamental rights. ${ }^{60}$

\section{Confusion between common values and corporate interests: a narrow margin of appreciation}

\footnotetext{
${ }^{54}$ Ibid, para 122

${ }^{55}$ For a critical appraisal of the case, see Myriam Hunter-Henin (n 26).

${ }^{56}$ The Law was voted by an overwhelming 335/1 majority before the Lower House of the French Parliament and a 246/1 majority before the Upper House.

${ }^{57}$ On the ECtHR's caution not to tread on Church/State constitutional national arrangements, see Rex Adhar and Ian Leigh, 'PostSecularism and the European Court of Human Rights: Or how God never really went away' (2012) 75(6) MLR 1064.

${ }^{58}$ See the French parliamentary resolution adopted on 11 May 2010 (Ass Nat XIII législature, TA no 459; (2010) JCP, Comments by Anne Levade, 551.

${ }^{59}$ Conseil Constitutionnel 7 October 2010, Journal Officiel 12 October 2010, 18345

${ }^{60}$ See however supporting this new social responsibility conferred upon employers, I Desbarats, 'Affaire Baby Loup: l'orthodoxie en guise d'épilogue' (2014) JCP 1445; adde, M Lamarche, 'Des femmes, des voiles, des enfants et des juges circonspects' (2014) JCP 902.
} 
This paragraph will examine whether this unusual entanglement of national and corporate interests justifies a wider or narrower margin of appreciation. Having rejected the arguments in favour of the former, it will conclude in favour of the latter. In one sense, cases between private parties usually warrant a wider margin of appreciation than cases involving individual claims against the State. The ECHR framework was indeed initially conceived to protect individuals against state interferences. Since then, the protection of the convention has been extended to horizontal relationships, to conflicts between private citizens. Under the doctrine of positive obligations, ${ }^{61}$ Member States are not only under the passive obligation to refrain from infringing the conventional human rights, they also have to take positive steps - hence the doctrine of positive duties - to deter violations by private parties. The assumption has however remained that the vertical dimension, the protection against the State, is the normal way of enforcing human right provisions. Because of this assumption, the ECtHR has therefore traditionally been more deferential towards States in the context of private law litigation. ${ }^{62}$ In the landmark case of Plattform Arzte für das Leben v Austria, the applicant organisation had complained that the Austrian authorities had not taken sufficient measures to prevent counter-demonstrators from disrupting their demonstrations. The case therefore entailed a conflict between two article 11 rights to freedom of assembly: the applicants' (who wished to demonstrate against legalised abortion) and the opposing private parties (who had organised disruptive counter-demonstrations). The ECtHR held that 'while it was the duties of parties to the Convention to take reasonable and appropriate measures to enable lawful demonstrations to proceed peacefully, they could not guarantee that absolutely and they had a wide discretion'. The situation is however different in the Baby Loup scenario. These conflicting rights would not belong to the private litigants. In Baby Loup, the employer is not opposing to the employee's religious freedom claim his own fundamental rights. He is privileging parental preferences for a religiously neutral environment over employees' rights to religious expression. Far from signalling an instance of 'clashing rights', ${ }^{63}$ the conflicting interests thus oppose fundamental rights to commercial concerns. However these corporate concerns for customer preferences coincide with national interpretations of children's best interests. Recent ECtHR case-law provides indication as to how this complex imbrication of corporate and national interests might be assessed in Strasbourg.

\section{Confusion between corporate and national interests: comparison with Ladele and Eweida ${ }^{64}$}

\footnotetext{
${ }^{61}$ D Spielman, 'Obligations positives et effet horizontal des dispositions de la Convention', in L'Interprétation de la Convention européenne des droits de l'homme, Actes du Colloque de l'IEDH à Montpellier des 13 et 14 mars 1998, (Bruylant 1998), 161

${ }^{62}$ ECtHR 21 June 1988 Plattform Arzte fur das Leben v Austria Series A, N 139 (1991) 13 EHRR 204.

${ }^{63}$ See L Zucca, Constitutional Dilemmas- Conflicts of Fundamental Legal Rights in Europe and the USA (OUP, 2007)

${ }^{64}$ Supra (n 36).
} 
In Eweida and Others, the British national policy of sexual orientation equality was upheld against individual religious beliefs relatively easily (Ladele $)^{65}$ but collective interests (the image of the company) were subject to a stricter proportionality test (Eweida) ${ }^{66}$ In Eweida, a British Airway employee who had been told by her employer to conceal the cross she was wearing had raised an unsuccessful challenge on the basis of religious discrimination law before English domestic courts. The ECtHR held that the restriction imposed on Ms Eweida's freedom to manifest her religious beliefs was disproportionate and consequently that Ms Eweida's article 9 rights had been violated. Was the restriction imposed in Baby Loup merely protecting customers' preferences and hereby promoting the nursery's corporate image as in Eweida or was it designed to protect the rights of a vulnerable group, as in Ladele?

In Ladele, the local authority enjoyed discretion as to which registrars to appoint to conduct civil samesex partnerships. In deciding to require all registrars to also be designated as civil partnership registrars, the local authority claimed it was showing its full commitment to the equal opportunity and sexual orientation nondiscrimination policy pursued by the UK. It may be argued that had the equality policy been so paramount, the British State would not have afforded local authorities any discretion as to its enforcement. Besides, had Ms Ladele's request been accommodated for, the British national equality policy would not clearly have been violated nor any concrete rights of others violated ${ }^{67}$ No violation of convention rights would have ensued. Yet, because of the wide margin of appreciation recognized to the respondent State, the decision to deny Ms Ladele's request did not lead to any incompatibility with the Convention either. Should the reasoning be extended to Baby Loup? The discretion afforded to the employer in Baby Loup ${ }^{68}$ could be compared to that enjoyed by the local authority in Ladele and the overarching policy of equality pursued in Ladele to the goal of protecting children's rights allegedly sought in Baby Loup. The nursery assistant's religious rights would then need to give in just like Ms Ladele's objections to same-sex unions had to give way. The analogy between Ladele and Baby Loup is however in my view superficial. First, whereas in Ladele the contested discretion was granted to a public authority, it was delegated in Baby Loup to a private employer. Secondly, had Ms Ladele's request been granted, same-sex couples would have symbolically been set apart. On the other hand, allowing nursery employees to wear ostentatious religious symbols at work does not interfere -even symbolically- with children's rights. The analogy between Ladele and Baby Loup does not therefore hold. It is submitted that the more appropriate analogy is between Baby Loup and Eweida.

\footnotetext{
${ }^{65}$ Ladele v Islington BC (CA) [2009] EWCA Civ 1357.

${ }^{66}$ Eweida $v$ British Airways Plc [2010] EWCA Civ 80.

${ }_{68}^{67}$ See I Leigh \& A Hambler, 'Religious Symbols. Conscience and the Rights of Others' (2014) 3(1) OJLR 2.

${ }^{68}$ Supra 1.
} 
In both Baby Loup and Eweida, corporate interests are opposed to individual religious rights. The Cour de cassation in Baby Loup proclaims that children's rights come first ${ }^{69}$ but does not explain in what way children's rights are at stake. The Cour de cassation seems to suggest that children attending the nursery should be spared the consequences of the religious rights conferred upon nursery staff. Tellingly the Procureur Général argues that just as religious parents can send their children to private faith nurseries, fairness would postulate accommodating atheist parental views in private non-faith nurseries. ${ }^{70}$ The real aim of the restriction therefore in fact lies in the desire to accommodate parental religious (or non-religious) preferences. However unless their rights are affected by the manifestation of Muslim religious beliefs, parental preferences cannot legitimately justify curtailing others' rights to express their faith. ${ }^{71}$ Certainly, parents' views are to receive particular attention in an educational context. Under article 2 protocol 1 of the ECHR, the State is to 'respect the right of parents to ensure such education and teaching in conformity with their own religious and philosophical convictions'. However these prerogatives do not allow parents to demand that their children escape all contact with other beliefs. They can only object to indoctrination of their children. ${ }^{72}$

In the paragraph to follow, I will contend that the mere fact for nursery assistants to be wearing a hiljab does not equate to indoctrination. In the Lautsi case, ${ }^{73}$ the ECtHR suggested that the mere presence of a religious symbol could not in itself amount to indoctrination. Less convincingly, the Court added in Lautsi that the crucifix was devoid of indoctrinating effect because it was only 'passive'. A symbol worn by a teacher or nursery assistant, by contrast, might hence be characterized as 'active' and therefore be construed as having a more 'powerful' impact on children than a static sign hanging on classroom walls. The distinction would however be arbitrary. A static symbol may speak volumes. ${ }^{74}$ Moreover it would be rather paradoxical for the ECtHR to protect symbols affixed by state authorities more strongly than symbols worn by individual teachers and employees. Whereas the State is not a human right holder, the individual teacher or employee is entitled to express their religious faith under article 9 of the Convention. Since Lautsi, the ECtHR has taken more care in assessing the personal motivations of religious symbol wearers. In $S A S$, it thus strongly rejected unilateral descriptions of the burqa as a symbol of oppression against women. ${ }^{75}$ Moreover in the cases of Mennesson and

\footnotetext{
${ }^{69}$ J-E Ray, 'Baby Loup. Les enfants d'abord!' (2014) JCP 804.

${ }^{70}$ Opinion, Supra (n 17).

${ }^{71}$ See CJUE 10 July 2008 C-54/07, (2010) JCP S 1421, J Cavallini.

${ }^{72}$ On the concept of indoctrination in the ECtHR case-law., see Myriam Hunter-Henin, 'Law, Religion and the School', in S Ferrari, Handbook on Law and Religion (Routledge 2015), 259.

${ }^{73}$ ECtHR 18 March 2011 Lautsi v Italy (App no 30814/06).

${ }^{74}$ On the multiple significations that may be assigned to the crucifix in the Lautsi case, see J Temperman (ed), The Lautsi Papers:

Multidisciplinary Reflections on Religious Symbols in the Public School Classroom (Martinus Nijhoff 2012).

${ }^{75}$ Supra (n 43), para 119.
} 
Labasse $v$ France, ${ }^{76}$ the ECtHR dismissed the purely abstract assessment made of children's rights and best interests in surrogacy contexts. ${ }^{77}$ By analogy, it is submitted that the Court is likely to refuse abstract assumptions about the harmful or proselytising effect that the hiljab may have on young nursery children. In the absence of concrete evidence that the wearing of the hiljab by nursery assistants affects children's freedom of conscience, the restriction imposed by Baby Loup would not therefore meet ECHR requirements.

\section{CONCLUSION}

The Baby Loup final decision of 25 June 2014 put an end to six years of litigation. ${ }^{78}$ It has not however put an end to the underlying intense debates raised by the case. From a domestic perspective, the decision is ambiguous. It holds the principle of laïcité to be irrelevant to the case and yet reasons as if it were applicable. It claims to protect fundamental rights of children and yet make their protection dependent on the provisions of nursery policies. More broadly, the Baby Loup decision is illustrative of suspicions in France towards religion and of recent attempts to extend laïcité beyond the public sphere. ${ }^{79}$ As a result, religious freedoms in the workplace appear to be less protected in France than other civil liberties, at least in the childcare sector. ${ }^{80}$ This new ordering, as demonstrated in this article, is not compatible with ECHR requirements.

On the contrary, the ECtHR has reasserted the importance of religious freedoms. None of the techniques that the ECtHR has at times used to allow broad restrictions is likely to be applicable in a Baby Loup context. The wide margin of appreciation that France enjoyed in the SAS case is thus unlikely to apply in litigation opposing religious freedoms to corporate interests. The contracting out approach which used to put the onus on the employee (forced to change jobs or refrain from manifesting her beliefs) has now been disavowed. Similarly, attempts to restrict protection to core beliefs would no longer be approved. Moreover, the looser proportionality test that the ECtHR has used when article 9 rights conflict with national policies would not be called for. Despite appealing to children's fundamental rights, the Cour de cassation actually relies on corporate interests (as entrenched in the nursery's policy) to justify the interferences. In comparison to the huge burden

\footnotetext{
${ }^{76}$ ECtHR 26 June 2014 Mennesson v. France (application no. 65192/11) and Labassee v. France (no. 65941/11).

${ }^{77}$ If children's best interests may in abstracto justify that surrogacy be prohibited (so as to avoid the commodification and reification of children), consideration of children's interests in concreto demands that children born illegally out of surrogacy may nevertheless have their legal parentage recognised with their commissioning parents. As well as the widely different context of both cases, one important difference must however be noted: in Baby Loup the abstract assessment of the best interest principle did not contravene children's rights but the child care workers in contact with children. The surrogacy cases nevertheless confirm the recent ECtHR trend to avoid blank abstract assessments of right violations.

${ }^{78}$ Litigation has come to an end at domestic level. However the Cour de cassation plenary Chamber decision may now be challenged before the ECtHR. See supra (n 3).

${ }^{79}$ See S Hennette-Vauchez and V Valentin, L'Affaire Baby Loup ou la nouvelle laïcité (LGDJ 2014).

${ }^{80}$ The dismissal of a supermarket employee who had refused to remove her scarf was held to be void.

http://www.ouest-france.fr/carrefour-condamne-pour-avoir-licencie-une-salarie-voilee-2833628 accessed 27 October 2014.
} 
caused to the employee, these company's interests would not weigh much in Strasbourg. If Baby Loup were to be challenged in Strasbourg, it is therefore to be hoped that this new restriction to religious freedom would not be seen with the same leniency as the ban on the burqa was. 